\title{
Anal Cancer pN3 TNM Finding v6 and v7
}

National Cancer Institute

\section{Source}

National Cancer Institute. Anal Cancer pN3 TNM Finding v6 and v7. NCI Thesaurus. Code C67547.

Anal cancer with metastasis in perirectal and inguinal lymph nodes and/or bilateral internal iliac and/or inguinal lymph nodes. (from AJCC 6th and 7th Eds.) 